\title{
III. BATHYMETRIC MAP OF THE EASTERN INDIAN OCEAN
}

\author{
Rudi G. Markl, Lamont-Doherty Geological Observatory, Columbia University, Palisades, New York
}

\begin{abstract}
A bathymetric map of the southern Wharton Basin sector of the eastern Indian Ocean has been constructed (see pocket). The area mapped $\left(90^{\circ}-120^{\circ} \mathrm{E} ; 24^{\circ}-40^{\circ} \mathrm{S}\right)$ also includes Broken Ridge, Naturaliste Plateau, the Diamantina Fracture Zone, and the northern extremity of the Southeast Indian Ridge. Heretofore, large portions of the sea-floor topography of this region have not been mapped in detail. Heezen and Tharp (1964) rendered the gross features of the region in their physiographic diagram of the Indian Ocean. Preliminary maps of a forthcoming atlas (Udintsev, in preparation) show the major features as well as the details of the region north of $27^{\circ} \mathrm{S}$. Falvey (1972) contoured the Australian continental margin south to $29^{\circ} \mathrm{S}$ and westward to $108^{\circ} \mathrm{E}$ at an interval of 500 meters using Australian Hydrographic Office data. Sclater and Fisher (1974) produced a map (500-m contour interval) of the northwest portion of the region which extends south to $31^{\circ} \mathrm{S}$ and eastward to $103^{\circ} \mathrm{E}$. Hayes and Conolly (1972) authored a map (100-fathom contour interval) of the region south of Australia which extends westward to $109^{\circ} \mathrm{E}$ and north to $30^{\circ} \mathrm{S}$; their map antedates the acquisition of the majority of the higher quality data in this region. Finally, von der Borch (1968) mapped the Perth Submarine Canyon and environs.
\end{abstract}

The present map is based upon soundings collected by Lamont-Doherty Geological Observatory, the Deep Sea Drilling Project (JOIDES), and those compiled by the Australian Hydrographic Office from various sources. The data were plotted in corrected meters (Matthews, 1939) at a scale of 3.05 in./degree longitude and contoured at a 500-meter interval; as presented here, the scale is 0.765 in./degree longitude $(1: 4,000,000$ at $32^{\circ}$ latitude). The L-DGO data were collected during 16 cruises by R/V Vema (Cruises 16 and 18); R/V Robert D. Conrad (Cruises 8, 9, and 11); and USNS Eltanin (Cruises 35, 44-50, 53-55). With the exception of the Vema data and Conrad Cruise 8, satellite navigation was employed on these cruises. The DSDP data, Cruises 26, 27, and 28 of Glomar Challenger, are all satellite navigated. Only the L-DGO and DSDP control is shown on the bathymetric map. Satellite-navigated track is indicated by solid lines; nonsatellite track is shown by dashed lines. The bulk of the soundings available from this region have been compiled by the Australian Hydrographic Office on GEBCO (General Bathymetric Chart of the Oceans) sheets $379-381$ (24. $\left.30^{\circ} \mathrm{S}\right) ; 408-410\left(30^{\circ}-36^{\circ} \mathrm{S}\right)$; and $438-440\left(36^{\circ}-42^{\circ} \mathrm{S}\right)$. The scores of ships which have collected data annotated on these sheets cannot be enumerated here; however, the many cruises of H.M.A.S. Diamantina must be mentioned. A 1967 cruise of R/V Oceanographer (track shown on the GEBCO sheets) is believed to be the only available satellite-navigated track not shown on the bathymetric map presented here.

The track distribution is quite uneven in general, with several three to six square degree data gaps existing in otherwise adequately controlled areas. The western half of the map has the poorest control; the track density in the northern quarter of the eastern half is also low. Along the northern border, between $90^{\circ}-100^{\circ} \mathrm{E}$, the contours were matched to those of preliminary Russian maps (Udintsev, in preparation). The contours in the area between $29^{\circ}-37^{\circ} \mathrm{S}$ and from $108^{\circ} \mathrm{E}$ to the Australian continent, the portion of the map having the greatest track density, are abstracted from a 100-meter interval map based on the satellite navigated data; the great mass of GEBCO data was evaluated and incorporated in a nonliteral manner.

Where sufficient seismic reflection data were available, the relief and character of the basement as well as nuances of the overlying sediment cover were utilized to correlate features from track to track. With the exception of Vema Cruise 16 and Eltanin Cruise 46, seismic reflection data were collected on all of the tracks shown. The Vema track enters the map area near $32^{\circ} 20^{\prime} \mathrm{S}, 90^{\circ} \mathrm{E}$ and exits near $37^{\circ} 45^{\prime} \mathrm{S}, 120^{\circ} \mathrm{E}$ and the Eltanin track exits near $40^{\circ} \mathrm{S}, 115^{\circ} 20^{\prime} \mathrm{E}$ and reenters near $40^{\circ} \mathrm{S}, 101^{\circ} 25^{\prime} \mathrm{E}$. Representative seismic reflection profiles of Broken Ridge have been published by Ewing et al. (1969); of Naturaliste Plateau by Burckle et al. (1967); of Diamantina Fracture Zone by Houtz and Markl (1972).

One of the more striking features of the bathymetry is the $650-\mathrm{km}$-long, northwest-southeast-trending deep which touches the southwest corner of the Naturaliste Plateau. This partially sediment-filled fracture, referred to as the Naturaliste Fracture Zone by Markl (in press), is well defined from its junction with the Diamantina Fracture Zone north to $33^{\circ} 40^{\prime} \mathrm{S}$; no data exist between this latitude and $32^{\circ} 35^{\prime} \mathrm{S}$. However, the fact that both the strike of the fracture and the character of the stratified sediments within it are identical north and south of the data gap indicates that it is continuous, as shown. In fact, the fracture may extend even farther northward than indicated; the large topographic high (centered on $31^{\circ} \mathrm{S}, 105^{\circ} \mathrm{E}$ ) which lies on the projected fracture zone trend is very poorly defined.

The Naturaliste Fracture Zone, Perth Abyssal Plain, and the deeper valleys of the Diamantina Fracture Zone reach depths in excess of 5700 meters. The words "Diamantina Fracture Zone" mark the deepest valley of this complex feature. The deepest sounding in the area mapped $(7102 \mathrm{~m})$ was recorded in the Diamantina Fracture Zone at $34^{\circ} 55^{\prime} \mathrm{S} ; 102^{\circ} 30^{\prime} \mathrm{E}$ by Vema on Cruise 16. Exclusive of the continental margin, the shallowest 
sounding in the region is 563 meters; it was obtained by the ship Southern Cross in 1965 at $31^{\circ} 24^{\prime} \mathrm{S}, 95^{\circ} \mathrm{E}$ on Broken Ridge.

\section{ACKNOWLEDGMENTS}

The efforts of the staff of the scores of ships which have provided data as well as the contribution of the Australian Hydrographic Office are gratefully acknowledged. I thank $\mathrm{Mr}$. M. Schneck and his co-workers in the data reduction section of the Submarine Topography Department of LamontDoherty, and their counterparts at the various contributing institutions, whose dogged pursuit of errors in data acquisition and reduction serve to make these data more reliable. This research was supported by the National Science Foundation (Division of Environmental Sciences and Office of Polar Programs) and the Office of Naval Research.

\section{REFERENCES}

Burckle, L. H., Saito, T., and Ewing, M. 1967. A Cretaceous (Turonian) core from the Naturaliste plateau, southeast Indian ocean: Deep-Sea Res., v. 14, p. 421-426.

Ewing, M., Eittreim, S., Truchan, M., and Ewing, J., 1969. Sediment distribution in the Indian ocean: Deep-Sea Res., v. 16 , p. $231-248$.

Falvey, D. A., 1972. Unpublished Ph. D. thesis, Univ, of New South Wales.
Hayes, D. E., and Conolly, J. R., 1972. Morphology of the southeast Indian ocean. In Hayes, D. E. (Ed.), Antarctic oceanology II: The Australian-New Zealand Sector, Antarctic res. ser., v. 19: Washington (Am. Geophys. Union), p. $125-145$.

Heezen, B. C. and Tharp, M., 1964. Physiographic diagram of the Indian ocean, the Red sea, the South China sea, the Sulu sea, and the Celebes sea: New York (Geological Soc. Am.).

Houtz, R. E. and Markl, R. G., 1972. Seismic profiler data between Antarctica and Australia. In Hayes, D. E. (Ed.), Antarctic oceanology II: The Australian-New Zealand Sector, Antarctic res. ser., v. 19: Washington (Am. Geophys. Union), p. 147-164.

Markl, R. G., in press. Evidence for the breakup of eastern Gondwanaland by the Early Cretaceous: Nature.

Matthews, J. D., 1939. Tables of velocity of sound in pure water and sea water for use in echo sounding and echo ranging: London (Admiralty Hydrographic Dept.).

Sclater, J. G. and Fisher, R. L., 1974. The evolution of the east central Indian ocean, with emphasis on the tectonic setting of the Ninetyeast ridge: Geol. Soc. Am. Bull., v. 85, p.

Udintsev, G. B., in preparation. International GeophysicalGeological Atlas of the Indian Ocean.

von der Borch, C. C., 1968. Southern Australian submarine canyons: their distribution and ages: Marine Geol., v.6, p. 267-279. 